\title{
Challenges of external personnel marketing
}

\author{
Lubica Gajanova ${ }^{1, *}$ \\ ${ }^{1}$ University of Zilina, Faculty of Operation and Economics of Transport and Communications, \\ Department of Economics, Univerzitna 1, 01026 Zilina, Slovakia
}

\begin{abstract}
.
Research background: In the long term, employees are without a doubt the most important success factor for any company. Due to the demographic change, numerous companies are increasingly confronted with a shortage of skilled workers and are therefore facing the increased competition in gaining of the qualified employees. This challenge is exacerbated by a globalization, digitization and the change from an industrial society to a service one as well. In addition, the Slovak and worldwide labor market in the coming years will be characterized by a change of generation, which will form the majority of the available potential of the workforce. Against this background, aspects such as employer attractiveness and employer branding are becoming increasingly important and influential in the field of personnel management.

Purpose of the article: Due to demographic developments and the upcoming change of generation, companies will face the difficulty of inspiring qualified employees in the future. This creates numerous challenges for external personnel marketing. The overall goal of this paper is to contribute to the current state of research on the challenges of personnel marketing in the future.

Methods: The method of collecting data through a questionnaire and the contingency analysis to process the data were chosen for this research.

Findings \& Value added: The objective of the paper is to setting up specific recommendations for the use of external personnel marketing, against the background of changing requirements and attitudes of generation $\mathrm{Z}$.
\end{abstract}

Keywords: personnel marketing; generation Z; labor market

JEL Classification: $M 12 ; O 35$

\footnotetext{
*Corresponding author: lubica.gajanova@,fpedas.uniza.sk
} 


\section{Introduction}

A needs-oriented employee acquisition is essential for the recruitment, as it enables companies to achieve a competitive advantage as in the case of customer relations [1]. The needs of potential employees change with each generation, which is why communication and the tools used have to be constantly adapted [2]. Companies are still in the process of integrating Generation $Y$ into work processes, while the next generation is already entering the workforce [3]. Generation $\mathrm{Z}$ is the first to have grown up fully with digitization $[4,5]$. For this reason, the communication methods are redesigning, which also affects the recruitment of this age group [6]. The demographic change makes Generation $\mathrm{Z}$ all the more relevant for companies [7]. There will be fewer people of working age in the coming years, as the population in Slovakia is expected to age significantly and decline in the next few years. Until 2025, the population of the Slovak Republic will not fundamentally change. From about 2025, the population of Slovakia should start to decrease, while the reduction will be long-term and will have an accelerating tendency. A more important demographic characteristic than the population size is the level of population aging. It is well described by the average age of the population and the aging index. Both indicators clearly document the trend of intensive aging of the Slovak population. Population aging in Slovakia will be one of the most intensive in the entire European Union [8]. Subsequently, the economic factor labour in Slovakia is becoming a scarce commodity the shortage of skilled workers has been evident for some years. The problem is already classified as the greatest risk for the development of the company by companies themselves [9-11].

For companies and their personnel marketing, this means that they have to change and be optimized in order to counteract a shortage of skilled workers. It creates numerous challenges for external personnel marketing. In order to be able to survive in the long term, companies need a strategy how the organization can positively differentiate itself from its competitors [12] in terms of recruitment tools within the personnel marketing. Various channels and measures of externally directed personnel marketing communication are used to initiate, establish, and maintain contacts. They serve the targeted recruitment of potential employees or applicants as well as they inform the public and promote the improvement of the employer attractiveness. In order to achieve a long-term interest of the potential applicants in the company, a simultaneous use of different measures is necessary and the creation of experiences with every contact between the interested party and the company is important [13].

The main channels and measures of personnel marketing communication are subdivided into classic tools as well as offline and online measures. The classic tools are used frequently and can be used in both online and offline different channels [14]. The classic tools are print job advertisements, digital job advertisements, videos, top employer ranking. Personal recommendation, cooperation with schools, talent pool and job fair are included in the offline measures. Online measures consist of company's career website, career blogs, Social Networks (Facebook, Instagram, LinkedIn, and Twitter) and rating platforms.

The overall goal of this paper is to contribute to the current state of research on the challenges of personnel marketing in the future. Specifically, the aim is to identify the specifics of recruiting Generation $Z$ representatives in comparison with Generation Y. For research and practice, answering this question is relevant to the extent that Generation $Z$ has not yet or only partially entered the labour market. It is therefore worthwhile for companies to prepare sufficiently for this generation in order to be able to find suitable personnel. 


\section{Methodology}

A questionnaire survey was conducted for the purpose of obtaining the necessary primary data. Respondents were representatives of generations Y (45.58\%) and Z (54.42\%). A basic set of surveyed respondents was formed of Slovak citizens older than 15 years. That age limit was set as one of the essential prerequisite for employability, according to a valid Slovak law [15, 16]. Total number of the examined sample was 283 respondents. The survey was conducted in August 2020 by means of the CAWI method (Computer Assisted Web Interviewing) is interviewing using websites, portals and also emails. This method was used due to the digitalization of generation researched. The size of the representative sample was determined by the following equation:

$$
n \geq\left[t_{\alpha}^{\wedge} 2 \times p \times(1-p)\right] / d^{\wedge} 2
$$

Where: $\mathrm{n}$ - the minimum number of respondents; $\mathrm{t} \alpha$ - the critical value of the normal distribution at significance level $\alpha=0.05 ; \mathrm{p}$ - the likely sample proportion, expressed as a decimal; $\mathrm{d}-$ the confidence interval, expressed as a decimal [17].

The confidence level was set at $95 \%$. The critical value of the normal distribution at confidence level $\alpha=0.05$ was 1.96 . This is based on the fact, that $\%$ of the area of the normal distribution is within 1.96 standard deviations of the mean. For those cases where the likely sample proportion was not known, $\mathrm{p}$ was set at $50 \%$. The confidence interval was set at $6 \%$. With these parameters, the minimum sample size is 267 . So the number of respondents in the survey can be considered as sufficient [18]. Respondents could rate the suitability of the recruitment tool from their point of view with a 5-point Likert scale, where 1 was the lowest level (not suitable) and 5 was the highest one (very suitable).

In addition to the percentage comparison in the work, we analyze the data more comprehensively, using an index, an expression that measures each value based on its relative significance to the other values in the table [19]. The index indicates the relative significance of a particular value in a pivot table cell (nij) relative to other cells and the total number of responses (n). The index calculates the weigh that an item contributes to the overall total. The index compares each value to its row total, its column total, and the overall total, using a weighted average [20]. Put simply, the index expresses the degree of protrusion or backwardness in a given sample. That is, how much the index for a particular cell loses to or exceeds number 1 . If all values in the pivot table were equal, each value would have an index of 1 . If an index is less than 1, itis of less importance in its row and column. If an index is greater than 1, it is of greater importance in its row and column [21]. The formula for calculating the index is as follows:

$$
\text { Index }=(n i j \times n) /(n . j \times n i .)
$$

Where: nij - frequencies in the pivot table; $\mathrm{n}$ - sum of all frequencies in the pivot table; $\mathrm{n.j}$ - is sum of frequencies in pivot table rows; $\mathrm{ni}$ - sum of frequencies in pivot table columns [20].

\section{Results and Discussion}

The review of the classic tools used in external personnel marketing for the use of the application in discussion part is provided in Table 1. 
Table 1. Classic tools.

\begin{tabular}{|c|c|c|c|c|c|c|c|}
\hline \multicolumn{8}{|c|}{$\begin{array}{l}\text { Classic tools } \\
\text { Job advertisements - print }\end{array}$} \\
\hline & \multicolumn{3}{|c|}{ Generation Y } & \multicolumn{3}{|c|}{ Generation $\mathrm{Z}$} & Total \\
\hline & $\mathrm{N}$ & $\%$ & Index & $\mathrm{N}$ & $\%$ & Index & $\mathrm{N}$ \\
\hline not suitable & 15 & $12 \%$ & 0,609 & 39 & $25 \%$ & 1,327 & 54 \\
\hline not very suitable & 21 & $16 \%$ & 0,720 & 43 & $28 \%$ & 1,235 & 64 \\
\hline partially suitable & 39 & $30 \%$ & 1,296 & 27 & $18 \%$ & 0,752 & 66 \\
\hline mostly suitable & 31 & $24 \%$ & 1,193 & 26 & $17 \%$ & 0,838 & 57 \\
\hline very suitable & 23 & $18 \%$ & 1,201 & 19 & $12 \%$ & 0,831 & 42 \\
\hline Total & 129 & $100 \%$ & $\mathrm{x}$ & 154 & $100 \%$ & $\mathrm{x}$ & 283 \\
\hline \multicolumn{8}{|c|}{ Job advertisements - digital } \\
\hline & \multicolumn{3}{|c|}{ Generation Y } & \multicolumn{3}{|c|}{ Generation $\mathrm{Z}$} & Total \\
\hline & $\mathrm{N}$ & $\%$ & Index & $\mathrm{N}$ & $\%$ & Index & $\mathrm{N}$ \\
\hline not suitable & 10 & $8 \%$ & 0,997 & 12 & $8 \%$ & 1,002 & 22 \\
\hline not very suitable & 13 & $10 \%$ & 0,983 & 16 & $10 \%$ & 1,014 & 29 \\
\hline partially suitable & 25 & $19 \%$ & 0,979 & 31 & $20 \%$ & 1,017 & 56 \\
\hline mostly suitable & 45 & $35 \%$ & 1,039 & 50 & $32 \%$ & 0,967 & 95 \\
\hline very suitable & 36 & $28 \%$ & 0,975 & 45 & $29 \%$ & 1,021 & 81 \\
\hline Total & 129 & $100 \%$ & $\mathrm{x}$ & 154 & $100 \%$ & $\mathrm{x}$ & 283 \\
\hline \multicolumn{8}{|l|}{ Videos } \\
\hline & \multicolumn{3}{|c|}{ Generation $\mathrm{Y}$} & \multicolumn{3}{|c|}{ Generation Z } & Total \\
\hline & $\mathrm{N}$ & $\%$ & Index & $\mathrm{N}$ & $\%$ & Index & $\mathrm{N}$ \\
\hline not suitable & 10 & $8 \%$ & 0,997 & 12 & $8 \%$ & 1,002 & 22 \\
\hline not very suitable & 18 & $14 \%$ & 1,013 & 21 & $14 \%$ & 0,990 & 39 \\
\hline partially suitable & 26 & $20 \%$ & 1,019 & 30 & $19 \%$ & 0,984 & 56 \\
\hline mostly suitable & 26 & $20 \%$ & 0,815 & 44 & $29 \%$ & 1,155 & 70 \\
\hline very suitable & 49 & $38 \%$ & 1,120 & 47 & $31 \%$ & 0,900 & 96 \\
\hline Total & 129 & $100 \%$ & $\mathrm{x}$ & 154 & $100 \%$ & $\mathrm{x}$ & 283 \\
\hline \multicolumn{8}{|c|}{ Top employer ranking } \\
\hline & \multicolumn{3}{|c|}{ Generation Y } & \multicolumn{3}{|c|}{ Generation $\mathrm{Z}$} & Total \\
\hline & $\mathrm{N}$ & $\%$ & Index & $\mathrm{N}$ & $\%$ & Index & $\mathrm{N}$ \\
\hline not suitable & 13 & $10 \%$ & 1,019 & 15 & $10 \%$ & 0,984 & 28 \\
\hline not very suitable & 14 & $11 \%$ & 0,991 & 17 & $11 \%$ & 1,008 & 31 \\
\hline partially suitable & 14 & $11 \%$ & 0,991 & 17 & $11 \%$ & 1,008 & 31 \\
\hline mostly suitable & 49 & $38 \%$ & 1,034 & 55 & $36 \%$ & 0,972 & 104 \\
\hline very suitable & 39 & $30 \%$ & 0,961 & 50 & $32 \%$ & 1,032 & 89 \\
\hline Total & 129 & $100 \%$ & $\mathrm{x}$ & 154 & $100 \%$ & $\mathrm{x}$ & 283 \\
\hline \multicolumn{8}{|c|}{ Employer image campaign } \\
\hline & \multicolumn{3}{|c|}{ Generation Y } & \multicolumn{3}{|c|}{ Generation Z } & Total \\
\hline & $\mathrm{N}$ & $\%$ & Index & $\mathrm{N}$ & $\%$ & Index & $\mathrm{N}$ \\
\hline not suitable & 8 & $6 \%$ & 0,975 & 10 & $6 \%$ & 1,021 & 18 \\
\hline not very suitable & 15 & $12 \%$ & 0,997 & 18 & $12 \%$ & 1,002 & 33 \\
\hline partially suitable & 23 & $18 \%$ & 0,989 & 28 & $18 \%$ & 1,009 & 51 \\
\hline mostly suitable & 47 & $36 \%$ & 1,042 & 52 & $34 \%$ & 0,965 & 99 \\
\hline very suitable & 36 & $28 \%$ & 0,963 & 46 & $30 \%$ & 1,031 & 82 \\
\hline Total & 129 & $100 \%$ & $\mathrm{x}$ & 154 & $100 \%$ & $\mathrm{x}$ & 283 \\
\hline
\end{tabular}

Due to the high affinity for technology, the rapid development of the Internet and the noticeable decline in the use of print media among younger generations [13], it can be assumed that job advertisements in print media are only partially or not suitable for addressing generations $\mathrm{Y}$ and $\mathrm{Z}$. Addressing Generation $\mathrm{Y}$ through job advertisements in analogue media can be described as partially suitable, since older representatives of Generation Y in particular, compared to younger members of Millennials and Generation Z, 
are less influenced by the development of the Internet and digital media to have [22, 23]. With regard to Generation $Z$, who grew up with the existence of the Internet, it can therefore be assumed that advertisements in print media will not be successful. Digital job advertisements are therefore particularly suitable for addressing Generation Z, but they are also very well received by Generation Y.

In addition to the high consumption of audio-visual media, which is mainly recorded among younger people, videos are also seen by older generations as an attractive way of conveying information. Against the background of the demand for authenticity on the part of generations $\mathrm{Y}$ and $\mathrm{Z}$ as well as increasing mediatisation, the video tool represents an attractive, cross-generational measure for conveying information and profiling the company as an employer [3]. Audio*visual media can therefore be described as very suitable for generations $\mathrm{Y}$ and mostly suitable for generation $\mathrm{Z}$.

In view of the vast increase in the number of options available in recent years, there is an increased desire for security and orientation on the part of the younger generations, which is evident not only in the need for authenticity but also in the area of career choice [4]. With the use of employer ranking in the context of external personnel marketing, companies can create trust and credibility with potential applicants by externalizing employer quality. Due to the large number of existing employer rankings, the usability is slightly restricted, since representatives of Generation $\mathrm{Y}$ in particular question the credibility of the rankings through their scepticism and constant questioning [24].

The similar classic tool is the image campaigns. If the company is to be presented as a brand and an attractive employer in the context of the employer brand [12], a decisive advantage of this tool can be used when addressing generations $\mathrm{Y}$ and $\mathrm{Z}$. Image campaigns are generally not tied to a specific medium and can therefore be used in different media for specific target groups [3]. Furthermore, it is also possible to adapt the content conveyed to the respective target group, so that this tool can be classified as mostly or very suitable for addressing both Generation $\mathrm{Y}$ and Generation $\mathrm{Z}$.

In the Table 2 the measures of offline area such as personal recommendation, cooperation with schools and universities, the establishment and maintenance of a talent pool and presence at job fairs are assessed.

Table 2. Offline measures.

\begin{tabular}{|c|c|c|c|c|c|c|c|}
\hline \multicolumn{8}{|c|}{$\begin{array}{l}\text { Offline measures } \\
\text { Personal recommendation }\end{array}$} \\
\hline & \multicolumn{3}{|c|}{ Generation Y } & \multicolumn{3}{|c|}{ Generation Z } & Total \\
\hline & $\mathrm{N}$ & $\%$ & Index & $\mathrm{N}$ & $\%$ & Index & $\mathrm{N}$ \\
\hline not suitable & 7 & $5 \%$ & 1,024 & 8 & $5 \%$ & 0,980 & 15 \\
\hline not very suitable & 13 & $10 \%$ & 0,983 & 16 & $10 \%$ & 1,014 & 29 \\
\hline partially suitable & 25 & $19 \%$ & 0,997 & 30 & $19 \%$ & 1,002 & 55 \\
\hline mostly suitable & 37 & $29 \%$ & 0,966 & 47 & $31 \%$ & 1,028 & 84 \\
\hline very suitable & 47 & $36 \%$ & 1,031 & 53 & $34 \%$ & 0,974 & 100 \\
\hline Total & 129 & $100 \%$ & $\mathrm{x}$ & 154 & $100 \%$ & $\mathrm{x}$ & 283 \\
\hline \multicolumn{8}{|c|}{ Cooperation with schools } \\
\hline & \multicolumn{3}{|c|}{ Generation Y } & \multicolumn{3}{|c|}{ Generation Z } & Total \\
\hline & $\bar{N}$ & $\%$ & Index & $\bar{N}$ & $\%$ & Index & $\overline{\mathrm{N}}$ \\
\hline not suitable & 8 & $6 \%$ & 0,975 & 10 & $6 \%$ & 1,021 & 18 \\
\hline not very suitable & 15 & $12 \%$ & 0,997 & 18 & $12 \%$ & 1,002 & 33 \\
\hline partially suitable & 23 & $18 \%$ & 0,989 & 28 & $18 \%$ & 1,009 & 51 \\
\hline mostly suitable & 47 & $36 \%$ & 1,042 & 52 & $34 \%$ & 0,965 & 99 \\
\hline very suitable & 36 & $28 \%$ & 0,963 & 46 & $30 \%$ & 1,031 & 82 \\
\hline Total & 129 & $100 \%$ & $\mathrm{x}$ & 154 & $100 \%$ & $\mathrm{x}$ & 283 \\
\hline
\end{tabular}




\begin{tabular}{|c|c|c|c|c|c|c|c|}
\hline \multicolumn{8}{|l|}{ Talent pool } \\
\hline & \multicolumn{3}{|c|}{ Generation $\mathrm{Y}$} & \multicolumn{3}{|c|}{ Generation $\mathrm{Z}$} & Total \\
\hline & $\mathrm{N}$ & $\%$ & Index & $\mathrm{N}$ & $\%$ & Index & $\mathrm{N}$ \\
\hline not suitable & 20 & $16 \%$ & 0,975 & 25 & $16 \%$ & 1,021 & 45 \\
\hline not very suitable & 24 & $19 \%$ & 0,993 & 29 & $19 \%$ & 1,006 & 53 \\
\hline partially suitable & 21 & $16 \%$ & 0,940 & 28 & $18 \%$ & 1,050 & 49 \\
\hline mostly suitable & 25 & $19 \%$ & 1,055 & 27 & $18 \%$ & 0,954 & 52 \\
\hline very suitable & 39 & $30 \%$ & 1,019 & 45 & $29 \%$ & 0,984 & 84 \\
\hline Total & 129 & $100 \%$ & $\mathrm{x}$ & 154 & $100 \%$ & $\mathrm{x}$ & 283 \\
\hline \multicolumn{8}{|l|}{ Job fair } \\
\hline & \multicolumn{3}{|c|}{ Generation Y } & \multicolumn{3}{|c|}{ Generation Z } & Total \\
\hline & $\mathrm{N}$ & $\%$ & Index & $\mathrm{N}$ & $\%$ & Index & $\mathrm{N}$ \\
\hline not suitable & 15 & $12 \%$ & 0,968 & 19 & $12 \%$ & 1,027 & 34 \\
\hline not very suitable & 29 & $22 \%$ & 0,979 & 36 & $23 \%$ & 1,018 & 65 \\
\hline partially suitable & 23 & $18 \%$ & 0,934 & 31 & $20 \%$ & 1,055 & 54 \\
\hline mostly suitable & 35 & $27 \%$ & 1,066 & 37 & $24 \%$ & 0,944 & 72 \\
\hline very suitable & 27 & $21 \%$ & 1,021 & 31 & $20 \%$ & 0,982 & 58 \\
\hline Total & 129 & $100 \%$ & $\mathrm{x}$ & 154 & $100 \%$ & $\mathrm{x}$ & 283 \\
\hline
\end{tabular}

In the offline area, the first aspect to be mentioned is the form of personal recommendation via word of mouth, which is very credible. This results from the recommendation of friends or acquaintances, which usually only occurs if they are satisfied [24]. As a result, the need of generations $\mathrm{Y}$ and $\mathrm{Z}$ for authenticity and security can be satisfied with the personal recommendation. This measure can therefore be assessed as very suitable for millennials and also as mostly suitable for Generation Z.

A cooperation offers the possibility of an exchange within the framework of events or the placement of internships. This creates an initial contact between the company and potential applicants, where the company and its image can be presented [12]. There is a huge possibility of using cooperation, because the $\mathrm{Z}$ generation has not yet or only partially entered the labour market $[4,5]$. Cooperation also enables to get to know potential employers who provide an unadulterated impression. Because of this, collaborations are categorized as mostly and very suitable for generations $\mathrm{Y}$ and $\mathrm{Z}$ in this assessment.

The creation of a talent pool primarily serves the company by helping to simplify the process of finding qualified applicants and to reduce recruiting costs. By bundling the contact details of people who have already worked in the company, a pool of potential applicants is available in the event of a vacant position. Against the background that many young people prefer to be approached by the company, a talent pool is a suitable measure for approaching potential applicants [3]. Addressing Generation Y by using a talent pool can therefore be classified as mostly suitable. Due to the current young age of Generation $\mathrm{Z}$ and so far little contact between them and the professional world, the talent pool is only suitable for addressing the oldest representatives of this generation at the moment.

Trade fairs are a largely or partially suitable external personnel marketing measure for addressing both Generation Y and Generation Z. In addition to direct addressing and communication, this measure also enables applicants and companies to get to know each other on an equal footing and is popular with both Generation Y and Generation Z [22]. The suitability of such trade fairs is weakened, however, by the high level of digitization, the importance of social networks and the importance of the use of smartphones, which Generation $\mathrm{Z}$ was more strongly influenced by than representatives of millennials [23]. These allow the assumption that there is increased activity on the Internet and thus also research into career or job choice in the digital environment. 
An assessment of possible measures in the online area with regard to addressing generations $\mathrm{Y}$ and $\mathrm{Z}$ follows. The individual evaluations can be found in Table 3 .

Table 3. Online measures.

\begin{tabular}{|c|c|c|c|c|c|c|c|}
\hline \multicolumn{8}{|l|}{$\begin{array}{l}\text { Online measures } \\
\text { Company` career website }\end{array}$} \\
\hline & \multicolumn{3}{|c|}{ Generation Y } & \multicolumn{3}{|c|}{ Generation $\mathrm{Z}$} & Total \\
\hline & $\mathrm{N}$ & $\%$ & & $\mathrm{~N}$ & $\%$ & & $\mathrm{~N}$ \\
\hline not suitable & 18 & $14 \%$ & 0,963 & 23 & $15 \%$ & 1,031 & 41 \\
\hline not very suitable & 25 & $19 \%$ & 0,979 & 31 & $20 \%$ & 1,017 & 56 \\
\hline partially suitable & 19 & $15 \%$ & 0,772 & 35 & $23 \%$ & 1,191 & 54 \\
\hline mostly suitable & 27 & $21 \%$ & 1,118 & 26 & $17 \%$ & 0,901 & 53 \\
\hline very suitable & 40 & $31 \%$ & 1,111 & 39 & $25 \%$ & 0,907 & 79 \\
\hline Total & 129 & $100 \%$ & $\mathrm{x}$ & 154 & $100 \%$ & $\mathrm{x}$ & 283 \\
\hline \multicolumn{8}{|l|}{ Career blogs } \\
\hline & \multicolumn{3}{|c|}{ Generation Y } & \multicolumn{3}{|c|}{ Generation $\mathrm{Z}$} & Total \\
\hline & $\mathrm{N}$ & $\%$ & & $\mathrm{~N}$ & $\%$ & & $\mathrm{~N}$ \\
\hline not suitable & 17 & $13 \%$ & 0,981 & 21 & $14 \%$ & 1,016 & 38 \\
\hline not very suitable & 19 & $15 \%$ & 0,906 & 27 & $18 \%$ & 1,079 & 46 \\
\hline partially suitable & 43 & $33 \%$ & 1,123 & 41 & $27 \%$ & 0,897 & 84 \\
\hline mostly suitable & 31 & $24 \%$ & 0,883 & 46 & $30 \%$ & 1,098 & 77 \\
\hline very suitable & 19 & $15 \%$ & 1,097 & 19 & $12 \%$ & 0,919 & 38 \\
\hline Total & 129 & $100 \%$ & $\mathrm{x}$ & 154 & $100 \%$ & $\mathrm{X}$ & 283 \\
\hline \multicolumn{8}{|c|}{ Social Networks - Facebook } \\
\hline & \multicolumn{3}{|c|}{ Generation Y } & \multicolumn{3}{|c|}{ Generation $\mathrm{Z}$} & Total \\
\hline & $\mathrm{N}$ & $\%$ & Index & $\mathrm{N}$ & $\%$ & Index & $\mathrm{N}$ \\
\hline not suitable & 15 & $12 \%$ & 0,997 & 18 & $12 \%$ & 1,002 & 33 \\
\hline not very suitable & 18 & $14 \%$ & 1,013 & 21 & $14 \%$ & 0,990 & 39 \\
\hline partially suitable & 24 & $19 \%$ & 1,013 & 28 & $18 \%$ & 0,990 & 52 \\
\hline mostly suitable & 31 & $24 \%$ & 0,958 & 40 & $26 \%$ & 1,035 & 71 \\
\hline very suitable & 41 & $32 \%$ & 1,022 & 47 & $31 \%$ & 0,981 & 88 \\
\hline Total & 129 & $100 \%$ & $\mathrm{x}$ & 154 & $100 \%$ & $\mathrm{x}$ & 283 \\
\hline \multicolumn{8}{|c|}{ Social Networks - Instagram } \\
\hline & \multicolumn{3}{|c|}{ Generation Y } & \multicolumn{3}{|c|}{ Generation Z } & Total \\
\hline & $\overline{\mathrm{N}}$ & $\%$ & Index & $\mathrm{N}$ & $\%$ & Index & $\mathrm{N}$ \\
\hline not suitable & 9 & $7 \%$ & 0,987 & 11 & $7 \%$ & 1,011 & 20 \\
\hline not very suitable & 21 & $16 \%$ & 1,024 & 24 & $16 \%$ & 0,980 & 45 \\
\hline partially suitable & 23 & $18 \%$ & 0,989 & 28 & $18 \%$ & 1,009 & 51 \\
\hline mostly suitable & 39 & $30 \%$ & 1,043 & 43 & $28 \%$ & 0,964 & 82 \\
\hline very suitable & 37 & $29 \%$ & 0,955 & 48 & $31 \%$ & 1,038 & 85 \\
\hline Total & 129 & $100 \%$ & $\mathrm{x}$ & 154 & $100 \%$ & $\mathrm{x}$ & 283 \\
\hline \multicolumn{8}{|c|}{ Social Networks - LinkedIn } \\
\hline & \multicolumn{3}{|c|}{ Generation Y } & \multicolumn{3}{|c|}{ Generation $\mathrm{Z}$} & Total \\
\hline & $\mathrm{N}$ & $\%$ & & $\mathrm{~N}$ & $\%$ & & $\mathrm{~N}$ \\
\hline not suitable & 20 & $16 \%$ & 0,997 & 24 & $16 \%$ & 1,002 & 44 \\
\hline not very suitable & 21 & $16 \%$ & 0,823 & 35 & $23 \%$ & 1,149 & 56 \\
\hline partially suitable & 30 & $23 \%$ & 0,954 & 39 & $25 \%$ & 1,039 & 69 \\
\hline mostly suitable & 35 & $27 \%$ & 1,181 & 30 & $19 \%$ & 0,848 & 65 \\
\hline very suitable & 23 & $18 \%$ & 1,030 & 26 & $17 \%$ & 0,975 & 49 \\
\hline Total & 129 & $100 \%$ & $\mathrm{x}$ & 154 & $100 \%$ & $\mathrm{x}$ & 283 \\
\hline \multicolumn{8}{|l|}{ Social Networks - Twitter } \\
\hline & \multicolumn{3}{|c|}{ Generation Y } & \multicolumn{3}{|c|}{ Generation Z } & Total \\
\hline & $\mathrm{N}$ & $\%$ & & $\mathrm{~N}$ & $\%$ & & $\mathrm{~N}$ \\
\hline not suitable & 23 & $18 \%$ & 1,147 & 21 & $14 \%$ & 0,877 & 44 \\
\hline not very suitable & 16 & $12 \%$ & 0,900 & 23 & $15 \%$ & 1,084 & 39 \\
\hline
\end{tabular}




\begin{tabular}{|c|c|c|c|c|c|c|c|}
\hline partially suitable & 47 & $36 \%$ & 1,159 & 42 & $27 \%$ & 0,867 & 89 \\
\hline mostly suitable & 26 & $20 \%$ & 0,803 & 45 & $29 \%$ & 1,165 & 71 \\
\hline very suitable & 17 & $13 \%$ & 0,932 & 23 & $15 \%$ & 1,057 & 40 \\
\hline Total & 129 & $100 \%$ & $\mathrm{x}$ & 154 & $100 \%$ & $\mathrm{x}$ & 283 \\
\hline \multicolumn{8}{|l|}{ Rating platforms } \\
\hline & \multicolumn{3}{|c|}{ Generation Y } & \multicolumn{3}{|c|}{ Generation $\mathrm{Z}$} & Total \\
\hline & $\mathrm{N}$ & $\%$ & Index & $\mathrm{N}$ & $\%$ & Index & $\mathrm{N}$ \\
\hline not suitable & 3 & $2 \%$ & 0,940 & 4 & $3 \%$ & 1,050 & 7 \\
\hline not very suitable & 11 & $9 \%$ & 1,005 & 13 & $8 \%$ & 0,995 & 24 \\
\hline partially suitable & 28 & $22 \%$ & 1,024 & 32 & $21 \%$ & 0,980 & 60 \\
\hline mostly suitable & 40 & $31 \%$ & 1,083 & 41 & $27 \%$ & 0,930 & 81 \\
\hline very suitable & 47 & $36 \%$ & 0,929 & 64 & $42 \%$ & 1,060 & 111 \\
\hline Total & 129 & $100 \%$ & $\mathrm{x}$ & 154 & $100 \%$ & $\mathrm{x}$ & 283 \\
\hline
\end{tabular}

Company-owned career websites are nowadays a standard measure to advertise vacant positions and to present information about the company in its function as an employer [2]. Due to their digital character and the technology affinity of generations $\mathrm{Y}$ and $\mathrm{Z}$, career websites are particularly suitable for addressing them [23]. When considering other factors and research results, however, the suitability of using career websites is questionable. Representatives of Generation Y, given the fact that they have already come into contact with companies, assessed the career websites as mostly suitable. In contrast to this, Generation $\mathrm{Z}$ is largely still in school or training [7], which allows the assumption that there is only little contact with companies and therefore the career website was therefore described as only partially suitable for Generation $\mathrm{Z}$ so far.

Career blogs can be classified as partially or mostly suitable in relation to generations $Y$ and $\mathrm{Z}$. However, due to the low impact of the Internet on early representatives of Generation Y, they are less active in Web 2.0 than later members of this generation or Generation $\mathrm{Z}$ [23]. This results in that the blogs communication platform is largely suitable for the youngest generation.

In addition to the development of the Internet, Generation Y was also shaped by the emergence of social networks that satisfy the desire for participation and confirmation. In the life of Generation $Z$, this desire and thus the importance of social networks has increased further [23]. For use in external personnel marketing, a distinction can be made between professional and predominantly private networks. The suitability of the Facebook network can be justified by the direct contact with the target group, the conveying of target group-specific content, the immediate reaction to comments, for example, as well as the unconventional and colloquial form of communication, that are considered important by the representatives of both generations. However, this channel is used more by Generation $Y$ then Generation $\mathrm{Z}$ and this illustrates the difference of suitability of perception between these age groups. The Instagram app is classified as very suitable for Generation Z. This assumption can be justified with the increased use of smartphones and the preference of informal, visual communication. Due to the fact that Generation $\mathrm{Y}$ is less influenced by smartphones, Instagram is classified as only mostly suitable at this point. The professional network LinkedIn can be used in particular to actively address representatives of Generation Y, as they have already entered or are about to enter professional life and are therefore increasingly active in professional networks. The use of these networks to address Generation $\mathrm{Z}$ is currently not very suitable due to their young age and their phase of life. It can be assumed that Twitter is particularly suitable for Generation $Z$, as they are more adept at handling new online applications due to a stronger influence of the Internet and mobile devices [23]. This type of communication also meets the preferences of Generation Z, which prefer short, informal texts as well as content that can be absorbed quickly.

The form of the rating platforms of companies on the Internet can be described as suitable for both generations. By sharing the experiences of current or former employees 
and applicants, authentic impressions can be conveyed [3, 22]. The need for orientation, security, transparency and authenticity that both generations have can be satisfied with the use of platforms.

\section{Conclusion}

Overall, it can be stated that the period of the coming years will be characterized by a continuous continuation of population aging while maintaining a relatively stable population size. The processes of population decline and aging will begin to accelerate significantly. It is also certain that such a development of the number and structure of the population will have far-reaching implications for the functioning of society and enterprises. It is essential for companies to recruit and retain suitable personnel in order to be able to survive in the competition. Due to demographic change and the shortage of skilled workers, this is becoming more and more complex for companies. Precautions that contribute to successful personnel marketing suitable for Generation $\mathrm{Z}$ are becoming more relevant. According to the results of the survey, these tools and measures are very suitable for the $\mathrm{Z}$ generation: digital job advertisements, top employer ranking, employer image campaign, cooperation with schools, Instagram, rating platforms. On the contrary, print job advertisements and LinkedIn are completely not or not very suitable ones.

This paper only takes into account the historical-social perspective, which defines the term generation through common value orientations. However, the classification of generations must also be viewed critically, because statements about generation-specific behaviour and values do not take into account the cultural and socio-economic influences of the various countries. On the other hand, the generation affiliation approach categorizes society and thus helps to simplify complex questions on this topic. Nevertheless, this approach is to be understood as more dynamic. People from different generations can behave similarly despite these different values. And this can cause the limits of the paper.

This paper is an output of scientific project VEGA no. 1/0718/18: The impact of psychographic aspects of pricing on the marketing strategy of companies across products and markets.

\section{References}

1. Nadanyiova, M. (2017). Neuromarketing - An opportunity or a threat?. Communications: scientific letters of the University of Žilina, 19(4), 90-94.

2. Hollowell, J. C., Rowland, Z., Kliestik, T., Kliestikova, J., Dengov, V. V. (2019). Customer Loyalty in the Sharing Economy Platforms: How Digital Personal Reputation and Feedback Systems Facilitate Interaction and Trust between Strangers. Journal of Self-Governance and Management Economics, 7(1), 13-18.

3. Bencsik, A., Horvath-Csikos, G., Juhasz, T. (2016). Y and Z Generations at Workplaces. Journal of Comeptitiveness, 8(3), 90-106.

4. Wilson, B. (2019). Marketing to Gen Z: The Rules for Reaching This Vast and Very Different Generation of Influencers. Journal of Macromarketing, 39(2), 228-230.

5. Southgate, D. (2017). The Emergence of Generation Z And Its Impact in Advertising Long-Term Implications For Media Planning and Creative Development. Journal of Advertising Research, 57(2), 227-235. 
6. Ple, L. (2019). Generation Z - From Z consumers to Z collaborators. Canadian Journal of Administrative Sciences-Revue Canadienne des Sciences de l Administration, 36(3), 450-451.

7. Svabova, L., Durica, M., Kramarova, K., Valaskova, K., Janoskova, K. (2019). Employability and Sustainability of Young Graduates in the Slovak Labour Market: Counterfactual Approach. Sustainability, 11(16), 4462.

8. Infostat (2013). Prognóza populačného vývoja Slovenskej republiky do roku 2060. Retrieved from: http://www.infostat.sk/vdc/pdf/prognoza07.pdf.

9. Institute for Competitive Recruiting (2012). DACH Recruiting Report. Retrieved from:https://competitiverecruiting.de/DACHRecruitingReport2012.html

10. Raven51 AG - HRM Research Institute GmbH (2017). Recruiting Intelligence Guide. Retrieved: https://www.personal-manager.at/fileadmin/PM/epaper/RIG_Online.pdf

11. Tumasjan, A., Kunze, F., Bruch, H., Welpe, I. M. (2020). Linking employer branding orientation and firm performance: Testing a dual mediation route of recruitment efficiency and positive affective climate. Human resource management, 59(1), 83-99.

12. Krizanova, A., Majerova, J. (2013). The proposal of activities of pricing policy in the process of building and managing brand value in Slovak Republic. In L. Zhang, X. Li \& J. Chen (Eds.), Proceedings of the 2013 International Conference on Information, Business and Education Technology (pp. 416-419). Bejing: Atlantis Press.

13. Zaušková, A., Rezníčková, M. (2020). SoLoMo marketing as a global tool for enhancing awareness of eco-innovations in Slovak business environment. Equilibrium. Quarterly Journal of Economics and Economic Policy, 15(1), 133-150.

14. Nadanyiova, M., Kramarova, K. (2013). Green Marketing and its Impacts on Consumers' Green Purchasing Behaviour. In J. Matus \& D. Petranova (Eds.), Proceedings of the International Scientific Conference on Marketing Identity: Design that Sells (pp. 423-435). Smolenice: UNIV SS CYRIL \& METHODIUS TRNAVA.

15. Krizanova, A., Majerova, J., Zvarikova, K. (2013). Green Marketing as a Tool of Achieving Competitive Advantage in Automotive. In Proceedings of the International Conference on Transport Means 2013 (pp. 45-48). Kaunas: Univ Technol Press.

16. Majerova, J. (2015). Analysis of Slovak Consumer's Perception of the Green Marketing Activities. In C. Bektas (Ed.), Proceedings of the World Conference on Business, Economics and Management (WCBEM) (pp. 553-560). Ephesus: Elsevier

17. Moravcikova, D., Krizanova, A., Kliestikova, J., (2017). Green Marketing as the Source of the Competitive Advantage of the Business. Sustainability, 9(12), 2218.

18. Valaskova, K., Kliestikova, J., Krizanova, A. (2018). Consumer Perception of Private Label Products: An Empirical Research. Journal of Competitiveness, 10(3), 149-163.

19. Parobek, J., Palus, H., Kalamarova, M., Loucanova, E., Supin, M., Krizanova, A., Stofkova, K. R. (2016). Energy Utilization of Renewable Resources in the European Union - Cluster Analysis Approach. BIORESOURE, 11(1), 984-995.

20. Dalgleish, D. (2007). Beginning Pivot Tables in Excel 2007. Apress.

21. Dalgleish, D. (2008). Excel 2007 PivotTables Recipes: A Problem-Solution. Apress.

22. Bejtkovsky, J. (2016). The Employees of Baby Boomers Generation, Generation X, Generation $\mathrm{Y}$ and Generation $\mathrm{Z}$ in Selected Czech Corporations as Conceivers of 
Development and Competitiveness in their Corporation. Journal of Comeptitiveness, 8(4), 105-123.

23. Perez-Escoda, A., Castro-Zubizarreta, A., Fandos-Igado, M. (2016). Digital Skills in the Z Generation: Key Questions for a Curricular Introduction in Primary School. Comunicar, 24(49), 71-79.

24. Cho, M., Bonn, M. A., Han, S. J. (2018). Generation Z's Sustainable Volunteering: Motivations, Attitudes and Job Performance. Sustainability, 10(5), 1400. 